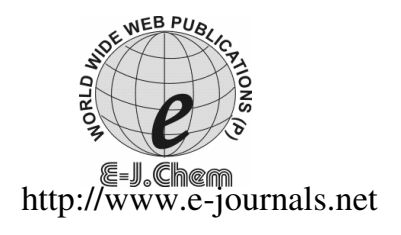

\title{
Spectrophotometric Methods for the Assay of Fluvoxamine Using Chromogenic Reagents
}

\author{
V. ANNAPURNA, G. JYOTHI, V. NAGALAKSHMI and B.B.V. SAILAJA* \\ Department of Chemistry, St. Theresa's College for Women, Eluru-534003, India. \\ *Andhra University, Visakhapatnam, Andhra Pradesh, India. \\ sailaja_bbv@yahoo.co.in
}

Received 25 November 2009; Accepted 20 January 2010

\begin{abstract}
Simple, accurate and reproducible UV-Visible spectrophotometric methods were established for the assay of FXA based on the oxidative coupling and condensation reactions. Condensation and coupling of the FXA with ninhydrin-ascorbic acid is proposed in method A. Method B includes complexation of FXA with cobalt thiocyanate. The ligating property of FXA with sodium nitro prusside is incorporated in method C. The optical characteristics such as Beers law limits, molar absorptivity and Sandell's sensitivity for the methods (A-C) are given. Regression analysis using the method of least squares was made to evaluate the slope(b), intercept(a) and correlation coefficient (r) and standard error of estimation (Se) for each system. Determination of FXA in bulk form and in pharmaceutical formulations were also incorporated.
\end{abstract}

Keywords: Estimation, Fluvoxamine, Precipitating agent, Charge transfer complex.

\section{Introduction}

Fluvoxamine $^{1}$ (as maleate FXA) is a selective serotonin reuptake inhibitor (SSRI) used to treat obsessive - compulsive disorder (OCD). It may also be used to treat depression and other conditions. It belongs to a new chemical series the 2- amino ethyl oxime ethers.

The mechanism of action of fluvoxamine maleate in obsessive compulsive disorder is presumed to be linked to its specific serotonin reuptake inhibition in brain neurons. In preclinical studies, it was found that fluvoximine inhibited neuronal uptake of serotonin.

A very few physico-chemical methods appeared in the literature for the assay of FXA in biological fluids and pharmaceutical formulations. Most of them are based on visible spectrophotometric methods ${ }^{2,3}$, HPLC $^{4-8}$, GC $^{9,10}$, fluorimetry ${ }^{11-13}$, LC-MS $^{14}$, GC-MS $^{15-17}$ \& $\mathrm{TLC}^{18}$, Mass ${ }^{19}$. The analytically useful functional groups in FXA have not been fully exploited for designing suitable, visible spectrophotometric methods and so still offer a scope to develop more visible spectrophotometric methods with better sensitivity, selectivity, precision and accuracy. The author has made some attempts in this direction and succeeded in developing few methods such as FXA with Brucine- $\mathrm{IO}_{4}{ }^{-}$in (Method A), with DCQC in (Method B) and with PDAC in (Method C). All these methods have been extended to pharmaceutical formulations as well. 


\section{Experimental}

An Elico, UV - Visible digital spectrophotometer with $1 \mathrm{~cm}$ matched quartz cells were used for the spectral and absorbance measurements. An Elico LI-120 digital pH meter was used for $\mathrm{pH}$ measurements.

All the chemicals and reagents used were analytical grade and the aqueous solutions were freshly prepared with triple distilled water. A $1 \mathrm{mg} / \mathrm{mL}$ solution was prepared by dissolving $100 \mathrm{mg}$ of pure FXA in $100 \mathrm{~mL}$ of $0.1 \mathrm{~N} \mathrm{HCl}$ and this stock solution was diluted step wise with distilled water to get the working standard solutions of required concentrations. Ninhydrin solution (BDH $\left.1 \%, 5.605 \times 10^{-5} \mathrm{M}\right)$ Ascorbic acid solution $\left(\mathrm{BDH} ; 0.1 \%, 5.678 \times 10^{-3} \mathrm{M}\right)$ Buffer solution( $\left.\mathrm{pH} 5.0\right)$

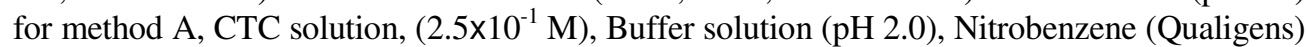
for method B, SNP Solution (E. Merck; 0.5\%, 1.678 $\times 10^{-2} \mathrm{M}$ ) HA Solution (Fluka; 0.5\%, $7.195 \times 10^{-2} \mathrm{M} \mathrm{Na}_{2} \mathrm{CO}_{3}$ solution (Loba; $10 \%, 9.43 \times 10^{-1} \mathrm{M}$ ) for method $\mathrm{C}$ were prepared.

\section{Method A}

Aliquots of standard FXA solution $(0.5 \mathrm{~mL} 2.5 \mathrm{~mL} ; 400 \mu \mathrm{g})$ was transferred into a series of calibrated tubes containing $4.0 \mathrm{~mL}$ of buffer $(\mathrm{pH} 5.0), 1.0 \mathrm{~mL}$ ninhydrin $\left(5.605 \times 10^{-5} \mathrm{M}\right)$ solution and $0.5 \mathrm{~mL}$ of ascorbic acid $\left(5.678 \times 10^{-3} \mathrm{M}\right)$ solution. The volume in each tube was adjusted to $8.0 \mathrm{~mL}$ with distilled water and was kept in boiling water bath. After 15 min tubes were removed and chilled in ice water. The solution in each tube was made up to $10.0 \mathrm{~mL}$ with distilled water. The absorbances were measured at $560 \mathrm{~nm}$ after $10 \mathrm{~min}$ against a reagent blank prepared similarly. The amount of FXA was calculated from its calibration graph (Figure 1)

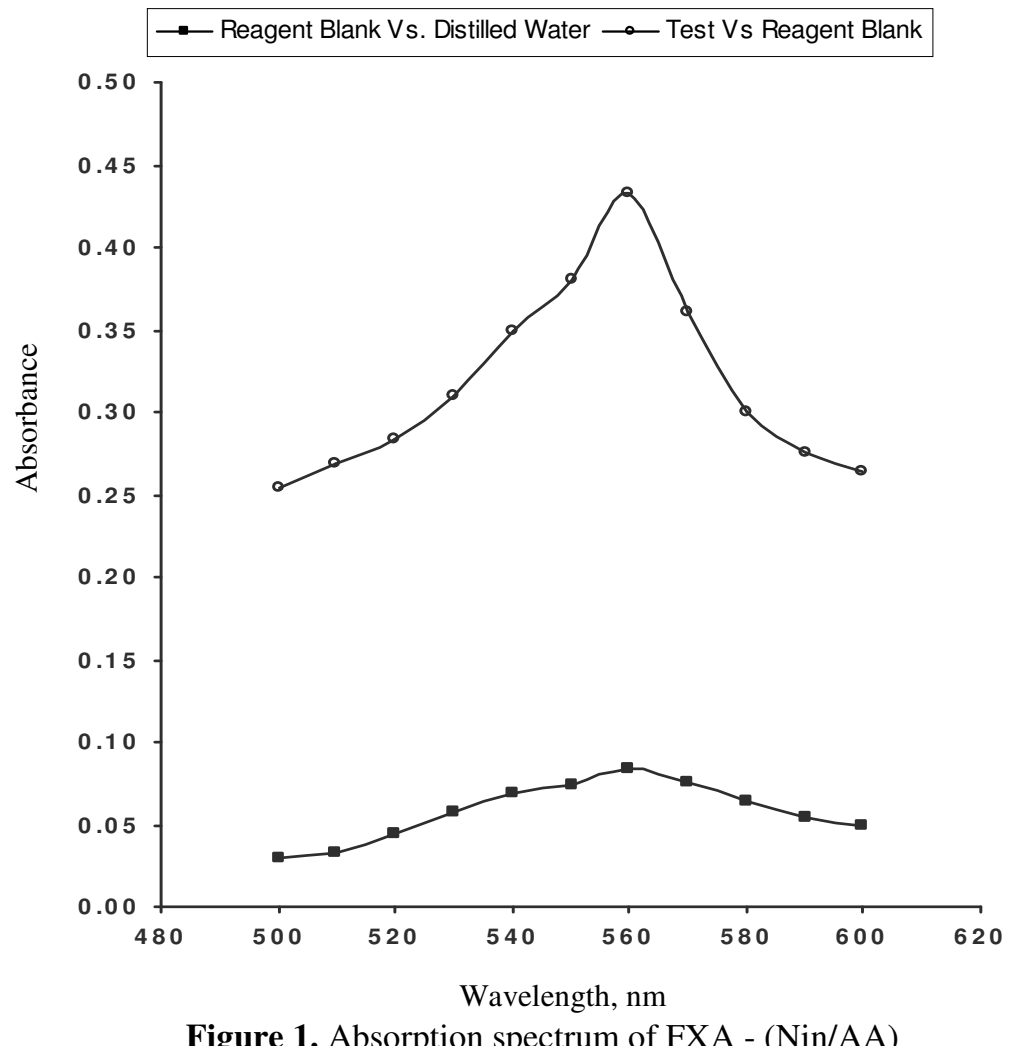

Figure 1. Absorption spectrum of FXA - (Nin/AA) 


\section{Method B}

Into a series of $125 \mathrm{~mL}$ of separating funnels, aliquots of standard FXA solution (0.5-3.0 mL, $\left.200 \mu \mathrm{g} . \mathrm{mL}^{-1}\right)$ were taken. Then $2.0 \mathrm{~mL}$ of buffer $(\mathrm{pH} 2.0)$ and $5.0 \mathrm{~mL}\left(2.5 \times 10^{-1} \mathrm{M}\right)$ of CTC solutions were added. The total volume of aqueous phase in each separating funnel was adjusted to $15.0 \mathrm{~mL}$ with distilled water. To each separating funnel, $10.0 \mathrm{~mL}$ of nitrobenzene was added and the contents were shaken for $2 \mathrm{~min}$. The two phases were allowed to separate and the absorbance of the separated nitrobenzene layer was measured at $620 \mathrm{~nm}$ against a similar reagent blank. The amount of FXA was computed from its calibration graph (Figure 2)

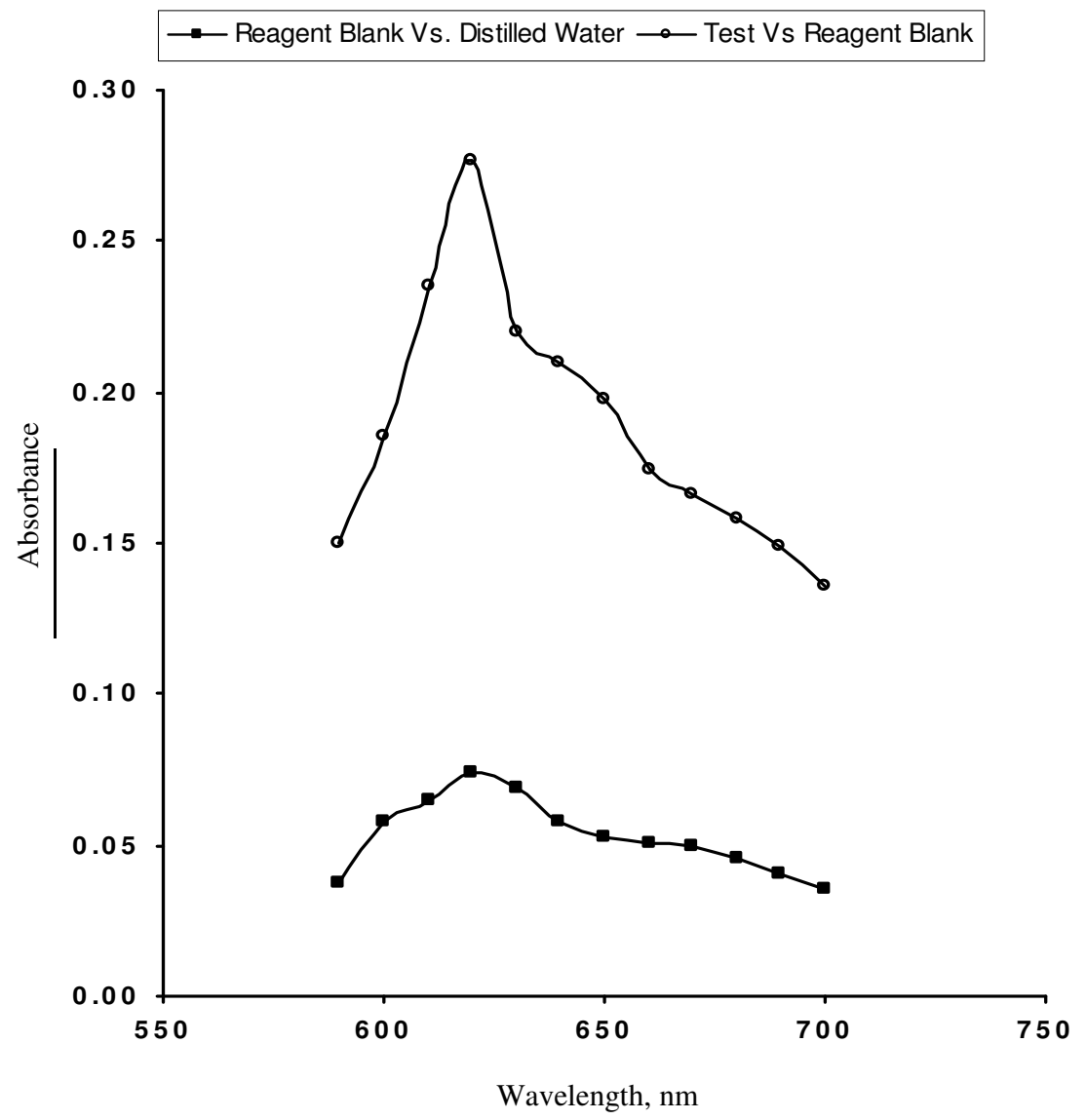

Method C

Figure 2. Absorption spectrum of FXA - CTC

Aliquots of standard FXA solution $\left(1.0-6.0 \mathrm{~mL}, 100 \mu \mathrm{g} \cdot \mathrm{mL}^{-1}\right)$ were transferred into a series of $25 \mathrm{~mL}$ calibrated tubes. Then $1.0 \mathrm{~mL}\left(1.678 \times 10^{-2} \mathrm{M}\right)$ of $\mathrm{SNP}$ and $1.0 \mathrm{~mL}$ $\left(7.195 \times 10^{-2} \mathrm{M}\right)$ of $\mathrm{HA}$ were added successively and kept aside for $5 \mathrm{~min}$. Then $1.0 \mathrm{~mL}$ $\left(9.43 \times 10^{-1} \mathrm{M}\right)$ of $\mathrm{Na}_{2} \mathrm{CO}_{3}$ solution was added and shaken for $15 \mathrm{~min}$. The volume was made up to the mark with distilled water. The absorbance was measured after $10 \mathrm{~min}$. at $440 \mathrm{~nm}$ against a similar reagent blank. The amount of FXA was computed from its calibration graph (Figure 3 ). 


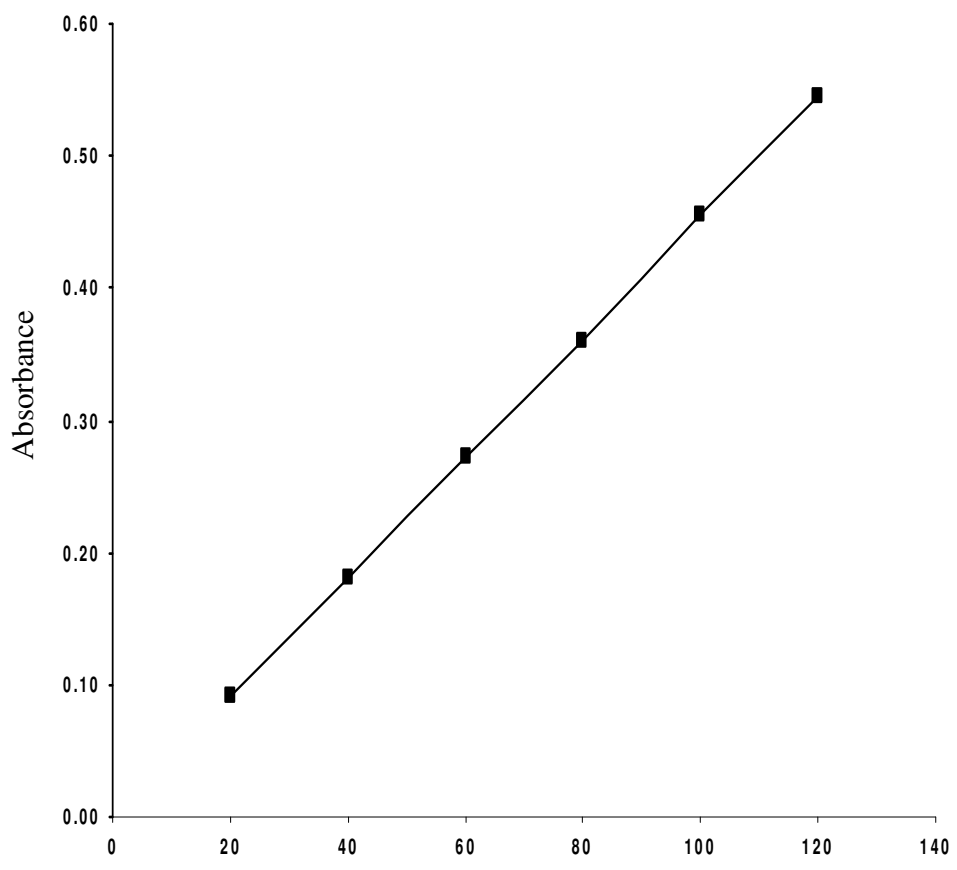

Structure of FXA

Figure 3. Beer's law plot of FXA - Nin/AA<smiles>CCOCCCC/C(=N\OCCN)c1ccc(C(F)(F)F)cc1</smiles>

(E)-5-methoxy-1-[4-trifluoro methyl) phenyl]-1-pentanone-O-2-amino ethyl) oxime; Method A

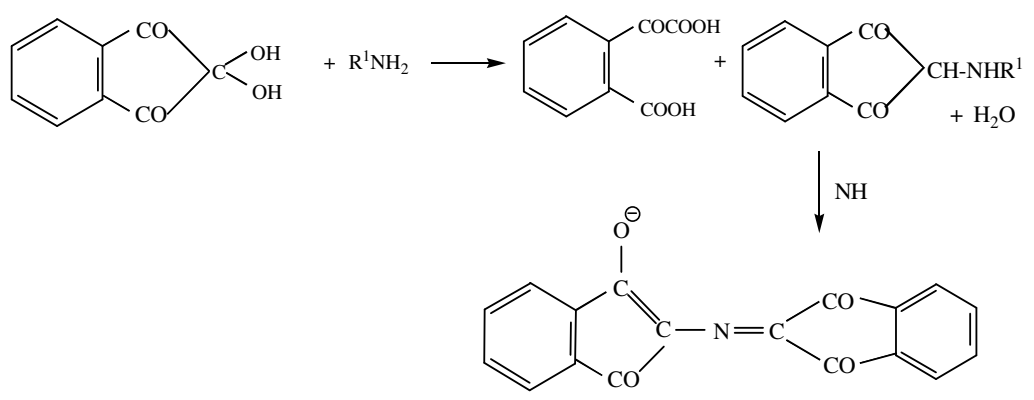

Method B

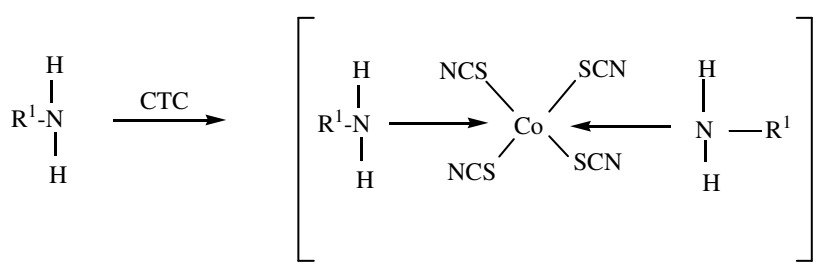




\section{Method C}

$$
\begin{aligned}
& \mathrm{Na}_{2}\left[\mathrm{Fe}(\mathrm{CN})_{5} \mathrm{NO}^{2-} \quad \frac{\mathrm{Na}_{2} \mathrm{CO}_{3}}{\mathrm{NH}_{2} \mathrm{OH}} \quad\left[\mathrm{Fe}(\mathrm{CN})_{5} \mathrm{H}_{2} \mathrm{O}\right]^{3-}\right. \\
& \downarrow \mathrm{R}^{1} \mathrm{NH}_{2} \\
& {\left[\begin{array}{lll}
\mathrm{Fe}(\mathrm{CN})_{5} & \mathrm{~N} \underset{\mathrm{H}}{-\mathrm{R}^{1}} \\
& \stackrel{-}{\mathrm{H}}
\end{array}\right]^{-3}}
\end{aligned}
$$

\section{Results and Discussion}

The optimum conditions for the color development of methods A, B and C were established by varying the parameters one at a time, keeping the others fixed and observing the effect produced on the absorbance of the colored species.

The optical characteristics such as Beer's law limits, molar absorptivity and Sandell's sensitivity for the methods (A-C) are given Table 1. The precision of the method to the drug was found by measuring the absorbance of six separate samples containing known amounts of drug and the results obtained are incorporated in Table 2. Regression analysis using the method of least squares was made to evaluate the slope (b), intercept (a) and correlation coefficient (r) and standard error of estimation (Se) for each system.

Table 1. List of proposed and reported visible spectrophotometric methods

\begin{tabular}{cccccc}
\hline \multirow{2}{*}{ Type of Reaction } & Reagent & Method & \multicolumn{3}{c}{ Optical characteristics } \\
\cline { 4 - 6 } & & & $\lambda_{\max } \mathrm{nm}$ & $\begin{array}{c}\in_{\max } 1 . \mathrm{mole}^{-1} \\
\mathrm{~cm}^{-1}\end{array}$ & $\begin{array}{c}\text { Beer's } \\
\text { limits } \mu \mathrm{g} \mathrm{mL} \mathrm{mL}^{-1}\end{array}$ \\
\hline Condensation & Nin or NH-AA & Method A & 560 & $1.542 \times 10^{3}$ & $20-120$ \\
Complex formation & CTC & Method B & 620 & $8.732 \times 10^{3}$ & $5-30$ \\
Inner complex formation & SNP-HA & Method C & 440 & $1.324 \times 10^{4}$ & $4-24$ \\
\hline
\end{tabular}

\begin{tabular}{|c|c|c|c|}
\hline Parameter & Method-A & Method-B & Method C \\
\hline$\lambda_{\max }, \mathrm{nm}$ & 560 & 620 & 430 \\
\hline Beer's law limits, $\mu \mathrm{g} / \mathrm{mL}$ & $20-120$ & $5-30$ & $4-24$ \\
\hline Detection limit, $\mu \mathrm{g} / \mathrm{mL}$ & 5.278 & 3.659 & 2.784 \\
\hline Molar absorptivity, $1 \mathrm{~mol}^{-1} \cdot \mathrm{cm}^{-1}$ & $1.542 \times 10^{3}$ & $8.732 \times 10^{3}$ & $1.3264 \times 10^{4}$ \\
\hline Sandell's sensitivity $\left(\mu \mathrm{g} . \mathrm{cm}^{-2} / 0.001\right.$ absorbance unit) & 0.3661 & 0.1352 & 0.1032 \\
\hline Optimum photometric range, $\mu \mathrm{g} / \mathrm{mL}$ & $25.12-120$ & $12.6-30$ & $8.318-20$ \\
\hline Regression equation $(\mathrm{Y}=\mathrm{a}+\mathrm{bc})$ slope $(\mathrm{b})$ & $3.768 \times 10^{-3}$ & 0.01796 & 0.02799 \\
\hline Standard deviation on slope $\left(\mathrm{S}_{\mathrm{b}}\right)$ & $1.198 \times 10^{-3}$ & $1.505 \times 10^{-2}$ & $2.115 \times 10^{-2}$ \\
\hline Intercept (a) & $7.5 \times 10^{-4}$ & $2.499 \times 10^{-3}$ & $2.25 \times 10^{-3}$ \\
\hline Standard deviation on intercept $\left(\mathrm{S}_{\mathrm{a}}\right)$ & $7.948 \times 10^{-2}$ & $2.495 \times 10^{-2}$ & $2.806 \times 10^{-1}$ \\
\hline Standard error on estimation $\left(\mathrm{S}_{\mathrm{e}}\right)$ & $7.579 \times 10^{-2}$ & $2.495 \times 10^{-2}$ & $2.676 \times 10^{-1}$ \\
\hline Correlation coefficient (r) & 0.9987 & 0.9995 & 0.9998 \\
\hline Relative standard deviation, $\%$ & 0.3535 & 0.8442 & 0.8094 \\
\hline 0.05 level & 0.4065 & 9706 & 0.9306 \\
\hline 0.01 level & 0.6374 & 1.522 & 1.459 \\
\hline$\%$ error in bulk samples & 0.196 & 0.126 & 0.139 \\
\hline
\end{tabular}

Table 2. Optical and regression characteristics, precision and accuracy of the proposed methods for FXA 
The accuracy of the methods was ascertained by comparing the results by proposed and reference methods statitistically by the $\mathrm{t}-$ and $\mathrm{F}$ - tests. The comparison shows that there is no significant difference between the results of studied methods and those of the reference ones. The similarity of the results is obvious evidence that during the application of these methods, the excipients are usually present in pharmaceutical formulations do not interfere in the assay of proposed methods. As an additional check of accuracy of the proposed methods, recovery experiments were carried out. The recovery of the added amounts of standard drug were studied at three different levels. Each level was repeated for six times. From the amount of drug found, the \% recovery was calculated in the usual way.

The higher $\lambda_{\max }$ values of all the proposed methods have a decisive advantage since the interference from the associated ingredients should be generally less at higher wavelengths than at lower wavelengths. Thus the proposed visible spectrophotometric methods are simple and sensitive with reasonable precision, accuracy and constitute better alternatives to the existing ones to the routine determination of FXA in bulk forms and pharmaceutical formulations (Table 3).

Table 3. Assay of FXA in pharmaceutical formulations

\begin{tabular}{|c|c|c|c|c|c|c|c|c|}
\hline \multirow{2}{*}{ 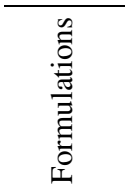 } & \multirow{2}{*}{ 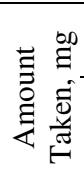 } & \multicolumn{4}{|c|}{ Amount found by proposed Methods } & \multicolumn{3}{|c|}{$\begin{array}{c}\text { Percentage recovery by } \\
\text { proposed methods }\end{array}$} \\
\hline & & $\begin{array}{l}\text { Method } \\
\text { A }\end{array}$ & $\begin{array}{l}\text { Method } \\
\text { B }\end{array}$ & $\begin{array}{l}\text { Method } \\
\text { C }\end{array}$ & $\begin{array}{l}\text { Reference } \\
\text { method }\end{array}$ & Method A & Method B & Method C \\
\hline Tablet I & 100 & $\begin{array}{l}99.83 \pm 0.49 \\
F=1.353 \\
t=0.915 \\
99.61 \pm 0.43\end{array}$ & $\begin{array}{l}100.01 \pm 0.45 \\
F=1.604 \\
t=1.562 \\
99.69 \pm 0.69\end{array}$ & $\begin{array}{l}100.03 \pm 0.43 \\
F=1.757 \\
t=1.162 \\
100.02 \pm 0.58\end{array}$ & $99.55 \pm 0.57$ & $99.94 \pm 0.25$ & $99.95 \pm 0.11$ & $99.93 \pm 0.32$ \\
\hline Tablet II & 100 & $\begin{array}{l}\mathrm{F}=3.5 \overline{4} 8 \\
\mathrm{t}=0.585 \\
99.73 \pm 0.34\end{array}$ & $\begin{array}{l}F=1.3 \overline{7} 80 \\
t=0.3002 \\
99.64 \pm 0.41\end{array}$ & $\begin{array}{l}F=1.9503 \\
t=0.473 \\
99.83 \pm 0.46\end{array}$ & $99.82 \pm 0.81$ & $99.93 \pm 0.32$ & $99.95 \pm 0.23$ & $99.96 \pm 0.17$ \\
\hline Tablet III & 100 & $\begin{array}{l}F=3.654 \\
t=0.8047 \\
99.52 \pm 0.47\end{array}$ & $\begin{array}{l}\mathrm{F}=2.513 \\
\mathrm{t}=1.045 \\
99.69 \pm 0.31\end{array}$ & $\begin{array}{l}F=1.996 \\
t=0.405 \\
99.53 \pm 0.42\end{array}$ & $99.96 \pm 0.65$ & $99.94 \pm 0.26$ & $99.92 \pm 0.16$ & $99.94 \pm 0.15$ \\
\hline Tablet IV & 100 & $\begin{array}{l}F=1.575 \\
t=1.372\end{array}$ & $\begin{array}{l}F=3.622 \\
t=0.96\end{array}$ & $\begin{array}{l}\mathrm{F}=1.9 \overline{7} 3 \\
\mathrm{t}=1.4\end{array}$ & $99.94 \pm 0.59$ & $99.96 \pm 0.31$ & $99.71 \pm 0.14$ & $99.94 \pm 0.25$ \\
\hline
\end{tabular}

\section{Conclusions}

The proposed methods exploit the various functional groups in FXA molecule. The decreasing order of sensitivity $\left(\epsilon_{\max }\right)$ among the proposed methods are (Method C $>$ Method B > Method A) respectively. The concomitants which do not contain the functional groups chosen in the present investigation do not interfere in the color development by proposed methods. Thus the proposed methods are simple, sensitive and selective with reasonable precision and accuracy and constitute better alternatives to the reported ones in the assay of FXA in bulk form and pharmaceutical formulations (Table 3).

\section{References}

1 The Merck Index, Merck \&Co Inc, New York, Ed.13, 2001, p.1803.

2 Aly F A, Mikrochim Acta., 1993, 100, 187-192.

3 Prasada Rao K V S, Nagaraju P, Prabhakar G, Begum J and Rasheed A, J Inst Chemists, 2004, 76, 19. 
4 Matsuda R, Yamamiya T, Tatsuzawa M, Ejima A and Takai N, J Chromatogr., 1979, A, 173, 75 .

5 Hesses, Christof, Lang and Erich, GIT Spez Chromatogr., 1996, 16, 100

6. Angelo H R, Herrstedt and Erich J, GIT Spez Chromatogr B., 1989, 496, 472.

7. Hattori H, Seno H, Ishil A, Yamada T. and Suzuki O, Nippon Lyo Masu Supekutoru Gakkai Koenshu, 1998, 23,137.

$8 \quad$ Li Wan Po A and Irwin W J, J High Resolut, Chromatogr., 1979, 2, 623.

$9 \quad$ Kaniewska T and Wejman W, Pol Farm, 1974, 30, 763.

10 Eblant-Goragia A, Balant L P, Gent C and Eisele R, Ther Drug Monit., 1985, 7, 229.

11 Shehata I A, El-Ashry S M, Sherbeny M A, EL Sherbeny D T and Belal F, J Pharm Biomed Anal., 2000, 22, 729-737.

12 Hassan S M, Belal F, Ibrahim F and Aly F A, Talanta, 1989, 36, 557.

13 Belal F, Ibrahim, Hassan S M and Aly F A, Anal Chim Act., 1991, 55, 103.

14 Kumazawa T, Seno H., Watanabe S, Kanako H, Hideki H, Akira S and Keizo O, $J$ Mass Spectrom., 2000, 35, 1091.

15 Clean S, Kane E J O and Smyth W F, J Chromatogr B Biomed Sci Appl., 2000, 740, 141.

16 Maurev H and Pfleger K, J Chromatogr., 1985, 306,.125.

17 Cailleux A, Turcant A, Premel-Cabic A and Allain P, J Chromatogr Sci., 1981, 19, 163.

18 El-Sherif Z. A., EL - Zeany B, EL-Houssinl O M, Rashed M S and Aboul-Enein H Y, Bio medical chromatography, 2004, 18(3),143.

19 Janiszewski J, Schneider R P, Haffmaster K, Swyden M, Wells D and Fouda H, Mass spectrometry, 1997, 11(9), 1033-1037. 


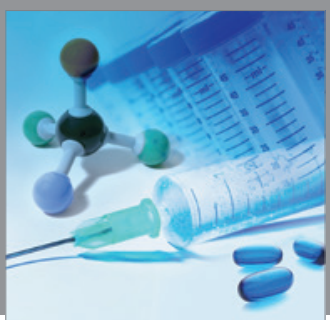

International Journal of

Medicinal Chemistry

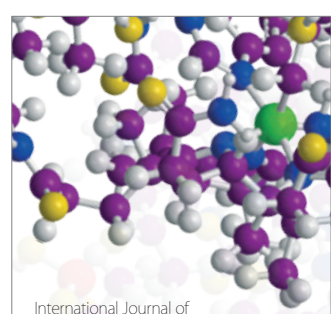

Carbohydrate Chemistry

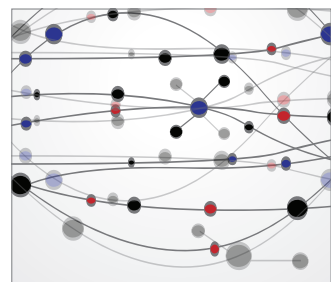

The Scientific World Journal
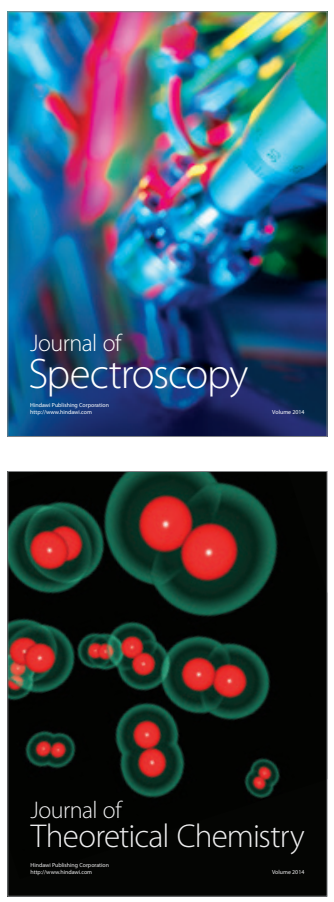
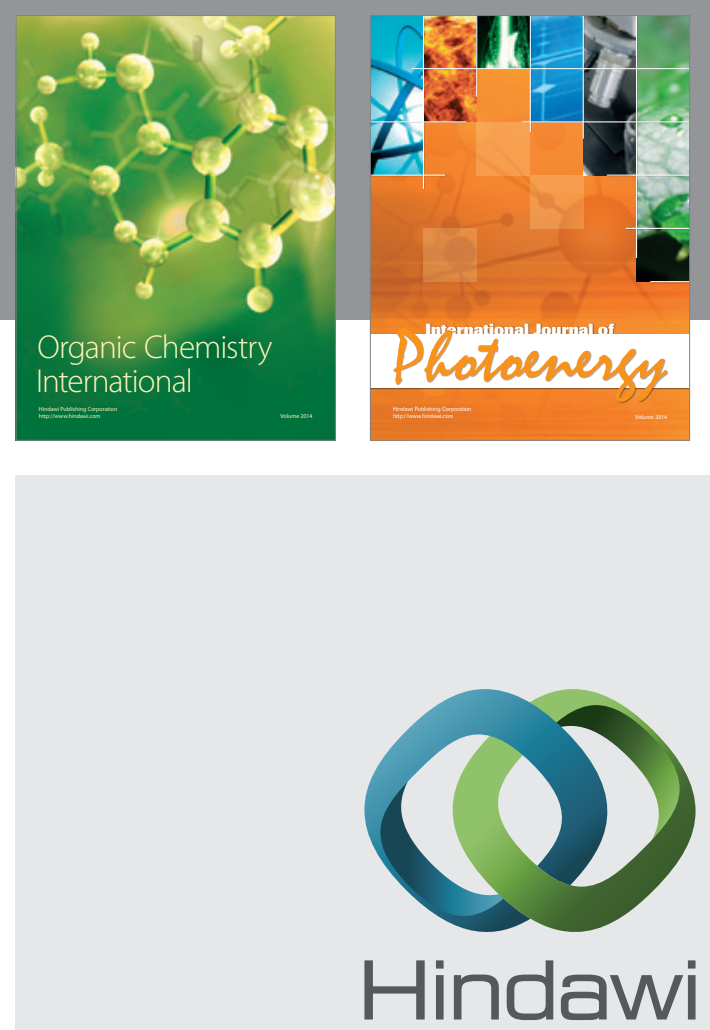

Submit your manuscripts at

http://www.hindawi.com
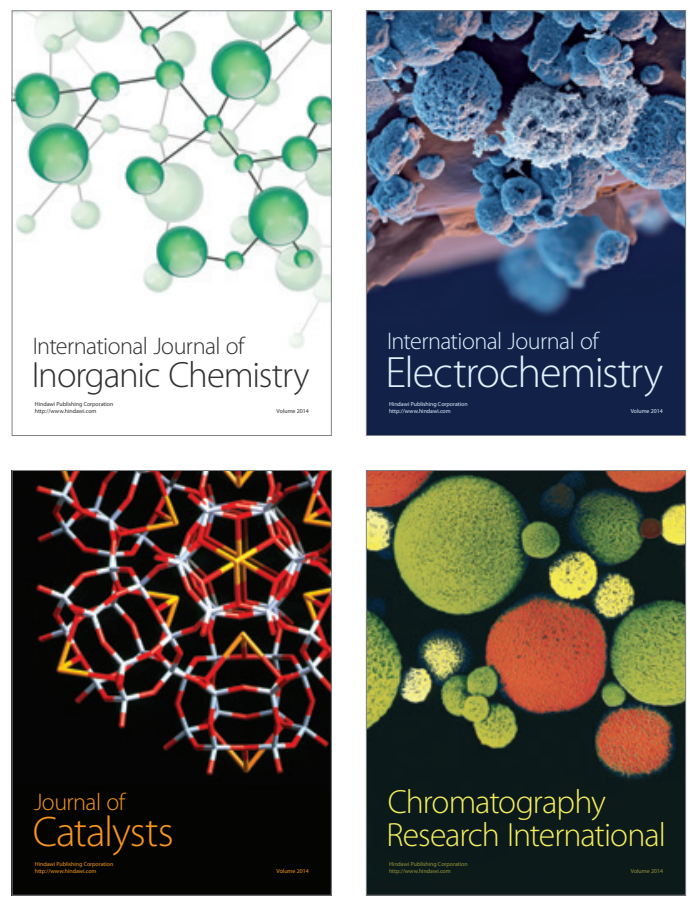
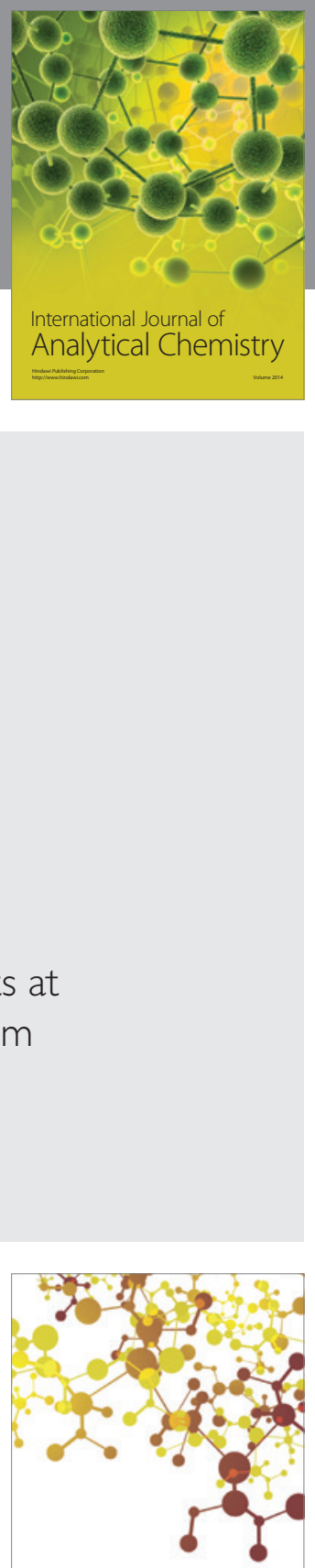

Journal of

Applied Chemistry
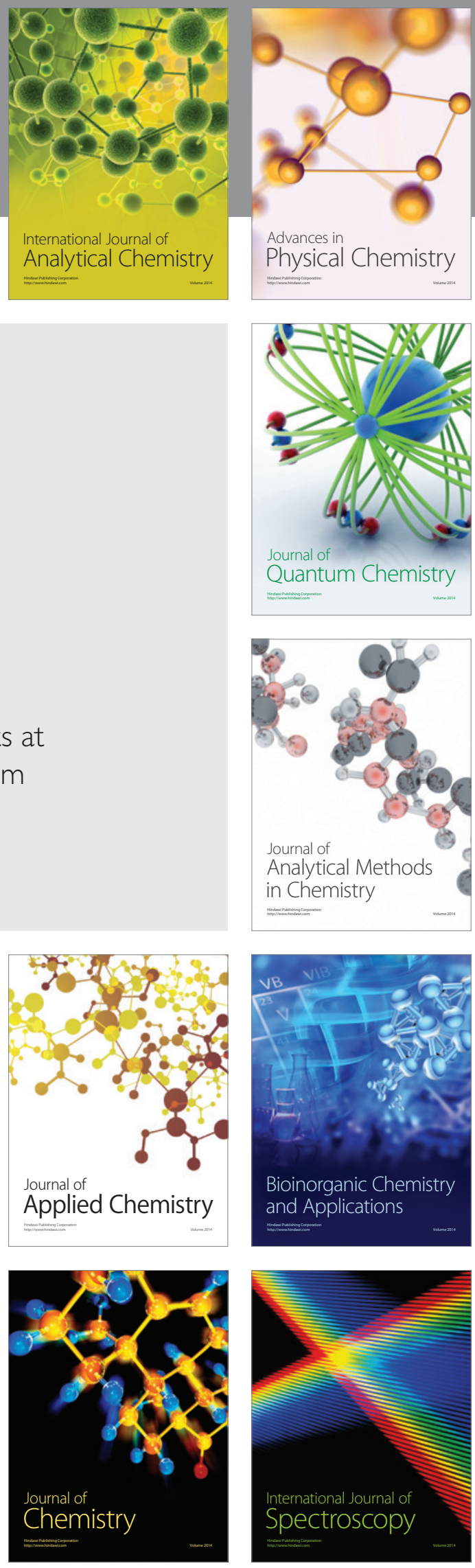